\title{
MAVENDI (MAGNETIC VENN DIAGRAM): MEDIA PEMBELAJARAN UNTUK MENINGKATKAN KEAKTIFAN SISWA DI ERA NORMAL BARU
}

\author{
Wasilatul Murtafiah $^{1}$, Siti Namiroh ${ }^{2}$, Darmadi ${ }^{3}$, Ika Krisdiana ${ }^{4}$, Titin Masfingatin ${ }^{5}$ \\ 1,2,3,4,5 Program Studi Pendidikan Matematika, Universitas PGRI Madiun \\ Email: wasila.mathedu@unipma.ac.id
}

\begin{abstract}
Abstrak:
Adanya pandemic COVID-19, pemerintah memutuskan untuk membiasakan kembali kehidupan dengan era normal baru. Pendidikan di era normal baru tentu memerlukan penyesuaian baru pada penyelenggaraan pembelajaran termasuk penyediaan media pembelajaran. Magnetic Venn Diagram (MAVENDI) dirancang sebagai media pembelajaran untuk meningkatkan keaktifan siswa pada materi Himpunan. Tujuan penelitian ini adalah untuk mengetahui hasil pengembangan MAVENDI untuk meningkatkan keaktifan belajar siswa di era normal baru pada materi Himpunan. Metode yang digunakan adalah penelitian dan pengembangan (R\&D) dengan model 4D yang difokuskan pada tahap pengembangan. Uji coba terbatas dilakukan pada 6 siswa dan uji coba lapangan pada 12 siswa kelas VII MTs Singo Walisongo Magetan, Jawa Timur. Pengumpulan data dengan menggunakan lembar angket validasi, angket respon dan observasi keaktifan siswa. Hasil dari pengembangan media ini dinyatakan cukup valid dengan presentase sebesar $88,59 \%$ berdasarkan angket validasi ahli, media ini memperoleh kriteria kepraktisan tinggi dengan nilai akhir pada uji coba terbatas sebesar $\mathrm{P}=4,23$ dan pada uji coba lapangan sebesar $\mathrm{P}=4,23$ berdasarkan angket respon siswa. Media ini dinyatakan efektif dengan memperoleh presentase sebesar $66,7 \%$ pada uji coba terbatas, sedangkan pada uji coba lapangan diperoleh $64,7 \%$ dengan kriteria aktif, berdasarkan observasi keaktifan siswa.
\end{abstract}

Kata Kunci: Mavendi, Media, Keaktifan, Era Normal Baru

\begin{abstract}
:
With the COVID-19 pandemic, the government has decided to get used to life with a new normal era. Education in the new normal era certainly requires new adjustments to the organization of learning including the provision of learning media. Magnetic Venn Diagrams (MAVENDI) are designed as learning media to increase student activity on the set material. The purpose of this study was to determine the results of the development of MAVENDI to improve student learning activities in the new normal era on the set material. The method used is research and development (R\&D) with the 4D model which is focused on the development stage. A limited trial was conducted on 6 students and a field trial on 12 VII grade students of Singo Walisongo Magetan, East Java. Data collection using a validation questionnaire sheet, questionnaire responses and observations of student activity. The results of the development of this media were declared to be quite valid with a percentage of $88.59 \%$ based on an expert validation questionnaire, this media obtained high practicality criteria with a final score on a limited trial of $\mathrm{P}=4.23$ and on a field trial of $\mathrm{P}=4.23$ based on student response questionnaire. This media was declared effective by obtaining a percentage of $66.7 \%$ in limited trials, whereas in field trials obtained $64.7 \%$ with active criteria, based on observations of student activity.
\end{abstract}

Keywords: Mavendi, Media, Activity, New Normal Era

\section{Pendahuluan}

Saat ini dunia sedang dihebohkan dengan adanya dampak pandemi Covid-19 (WHO, 2020), demikian halnya dengan Indonesia (Gugus Tugas Percepatan Penanganan COVID-19, 2020). Adanya pandemi ini menyebabkan perubahan yang mencolok diberbagai bidang salah satunya di bidang pendidikan. Perubahan yang drastis tampak pada pelaksanaan pendidikan di semua jenjang sekolah. Untuk menghentikan keterpurukan karena pandemi COVID-19 tersebut maka pemerintah memutuskan untuk 
membiasakan kembali kehidupan dengan era normal baru.

Pendidikan adalah interaksi yang terjadi antara guru dan siswa guna mendorong terjadinya kegiatan belajar mengajar (Vitasari, Joharman, \& Suryandari, 2013). Melalui kegiatan pembelajaran, siswa memperoleh pengetahuan serta keterampilan yang tentunya berguna untuk kehidupan seharihari. Guru memiliki peran penting sebagai pendidik yang menjadikan sumber daya manusia menjadi berkualitas (Murtafiah, Sa'dijah, Chandra, Susiswo, \& Zayyadi, 2020). Sumber daya manusia berkualitas dapat diwujudkan melalui pembelajaran efektif yang diselenggarakan oleh guru.

Salah satu pembelajaran yang penting diselenggarakan di sekolah adalah pembelajaran matematika. Hal ini dikarenakan matematika merupakan ilmu yang merupakan dasar dari pengembangan teknologi modern, yang juga memiliki peran penting untuk berbagai disiplin ilmu pengetahuan, dan dapat meningkatkan kemampuan berpikir manusia. Mulai jenjang pendidikan dasar sampai menengah, matematika penting diberikan untuk menyiapkan siswa agar mampu mengahadapi perkembangan seperti kondisi saat ini yaitu era normal baru. Melalui pembelajaran matematika siswa dilatih melakukan kegiatan berdasarkan berpikir logis, rasional, kritis. Meskipun demikian materi pembelajaran yang dianggap sulit oleh siswa adalah matematika (Arfinanti, 2014).

Dalam dunia pendidikan penggunaan media pembelajaran sangatlah penting, dan dapat menarik minat siswa selama proses belajar mengajar berlangsung (Ariska, Darmadi, \& Murtafiah, 2018). Melalui penggunaan media pembelajaran, siswa juga diharapkan aktif pada saat kegiatan belajar mengajar. Selain itu, suasana pembelajaran yang menyenangkan dapat diciptakan melalui media pembelajaran, sehingga pemecahan masalah dapat dilakukan dengan baik oleh siswa (Zayyadi, Hasanah, \& Muhaimin, 2018).

Kualitas pendidikan dapat ditingkatkan melalui media pembelajaran, termasuk pada kualitas pembelajaran matematika. Pemahaman siswa dapat dibangun melalui media pembelajaran, serta dapat memberikan penugasan bagi siswa dalam belajar. Penggunaan media pembelajaran dapat memudahkan siswa mengenal konsep maupun simbol matematika dari abstrak menjadi konkret. Dengan demikian pengenalan konsep dan simbol matematika dapat diberikan oleh guru sejak dini (Sundayana, 2013).

Keaktifan berpengaruh besar pada nilai hasil belajar siswa. Apabila hal yang dipelajari siswa tidak mampu memotivasi atau mengaktifkaan siswa maka dapat diduga bahwa siswa tidak akan belajar dengan sungguh-sungguh. Pada kegiatan belajar mengajar, keaktifan siswa merupakan faktor internal yang urgen untuk memotivasi siswa guna tercapainya suatu tujuan pembelajaran.

Penggunaan media pembelajaran dalam pembelajaran matematika diduga dapat meningkatkan keaktifan siswa. Guru harus menyesuaikan antara kondisi di lapangan denga media yang akan dikembangkan. Seperti kondisi saat ini, Kemendikbud memiliki panduan baru untuk pelaksanaan pembelajaran di era normal baru. Hal ini tentu memerlukan media pembelajaran yang sesuai karena waktu dan jumlah siswa yang masuk diatur guna memutus rantai COVID-19.

Himpunan merupakan materi pelajaran matematika yang dianggap tidak mudah oleh siswa MTs Singo Wlisongo Magetan adalah. Materi ini merupakan materi dasar untuk mempelajari konsepkonsep matematika selanjutnya. Kesulitan siswa diantaranya adalah siswa susah menggambarkan diagram venn sebagai bentuk representasi himpunan. Kesulitan yang dialami oleh siswa tersebut menyebabkan rendahnya keaktifan siswa dalam belajar, apalagi aturan belajar di era normal baru sekarang ini.

Media pembelajaran yang dirasa cocok untuk mengajarkan materi himpunan sekaligus untuk mengaktifkan siswa adalah magnetic venn diagram (MAVENDI). MAVENDI merupakan media pembelajaran yang dirancang untuk mendukung pembelajaran di era new 
normal. Media ini sangat sesuai jika digunakan untuk kegiatan pembelajaran dengan seting kelompok-kelompok belajar. MAVENDI dirancang dengan menggunakan magnet sehingga siswa secara aktif dapat mempelajari konsep himpunan.

\section{Metode Penelitian}

Penelitian ini menggunakan metode penelitian pengembangan (Research and Development). Metode penelitian Research and Development atau R\&D adalah metode penelitian yang digunakan untuk menciptakan produk baru atau produk yang ada disempurnakan (Sugiyono, 2017). Dalam penelitian ini yang dikembangkan adalah media pembelajaran MAVENDI. MAVENDI dikembangkan dengan model pengembangan yang sesuai dengan sistem pendidikan yaitu langkah-langkah penelitian pengembangan 4D menurut Thiagarajan, Semmel, \& Semmel (1974), yang meliputi: Define (pendefinisian), Design (perancangan), Development (pengembangan), dan Dissimination (penyebaran). Penelitian ini difokuskan pada tahap pengembangan media pembelajaran MAVENDI, sedangkan langkah pendefinisian dan perancangan telah dibahas pada bagian pendahuluan. Langkah penyebaran tidak dilakukan pada penelitian ini, mengingat keteerbatasan waktu dan biaya.

Uji coba terbatas pada langkah pengembangan adalah 6 orang siswa yang diambil secara acak oleh peneliti, sedangkan pada uji lapangan adalah 12 siswa kelas MTs Singo Walisongo, Magetan.

Instrumen penelitian ini adalah lembar angket validasi untuk mengetahui kevalidan MAVENDI, lembar angket respon siswa untuk mengetahui kepraktisan MAVENDI, dan observasi keaktifan siswa untuk mengetahui keefektifan MAVENDI.

\section{Validitas Media Pembelajaran}

Proses validasi media pembelajaran MAVENDI dilakukan oleh 3 validator/ahli, yaitu 2 guru matematika MTs Singo Walisongo Magetan dan 1 dosen
Pendidikan Matematika Universitas PGRI Madiun. Validasi ini dilakukan untuk memberi nilai dan saran demi kesempurnaan pengembangan media pembelajaran MAVENDI pada materi himpunan.

Data hasil validasi berupa angka yang dihitung menggunakan rumus untuk menentukan interval yang menyatakan media pembelajaran MAVENDI valid, kurang valid, atau tidak valid. Untuk menghitung presentase kevalidan (V) media ini digunakan rumus (Sa'dun Akbar, 2013):

$$
V=\frac{\text { Jumlah skor dari validator }}{\text { Jumlah skor maksimal }} \times 100 \%
$$
melibatkan lebih dari 1 validator, maka selanjutnya dihitung dengan rumus (S. Akbar, 2013):

$$
V=\frac{V_{1}+V_{2}+V_{3}}{3} x \ldots \%
$$

Pada penlitian ini, valid tidaknya suatu media pembelajaran MAVENDI yang telah dikembangkan dilihat berdasarkan kriteria validitas pada Tabel 1 (Akbar, 2013).

Tabel 1. Kriteria Validitas

\begin{tabular}{cl}
\hline Kriteria Validitas & \multicolumn{1}{c}{ Tingkat Validitas } \\
\hline $85,01 \%-100,00 \%$ & $\begin{array}{l}\text { Sangat valid, atau dapat } \\
\text { digunakan tanpa revisi. }\end{array}$ \\
$70,01 \%-85,00 \%$ & $\begin{array}{l}\text { Cukup valid, atau dapat } \\
\text { digunakan namun perlu } \\
\text { direvisi kecil. }\end{array}$ \\
& $\begin{array}{l}\text { Kurang } \\
\text { disarankan valid, tidak } \\
\text { digunakan karena perlu } \\
\text { revisi besar. } \\
\text { Tidak valid, atau tidak } \\
\text { boleh dipergunakan. }\end{array}$ \\
\hline
\end{tabular}

Media pembelajaran MAVENDI dikatakan valid apabila skor lebih dari $70,00 \%$. Apabila skor tidak memenuhi kriteria maka peniliti harus melakukan revisi terhadap media tersebut.

\section{Kepraktisan Media Pembelajaran}

Uji kepraktisan media pembelajaran MAVENDI diperoleh dari angket respon siswa setelah menggunakan media pembelajaran yang dikembangkan. Sikap, pendapat, dan persepsi siswa diukur 
menggunakan skala Likert melalui Angket respon siswa.

Skor respon siswa (responden) dijumlah dan dihitung untuk mengukur kepraktisan menggunakan rumus berikut (Handayani, Yuwono, \& Madja, 2013).

a. Menentukan rata-rata dari responden

untuk setiap kriteria

$$
I_{s j}=\frac{\sum_{1=1}^{n} \sum_{j=1}^{m} S_{i j}}{n}
$$

b. Menentukan nilai kepraktisan

$$
P=\frac{\sum_{j=1}^{n} I_{s j}}{m}
$$

Keterangan:

$I_{s j}=$ Skor rata-rata semua peserta didik untuk kriteria ke $\mathrm{j}$

$S_{i j}=$ Skor dari peserta didik ke terhadap kriteria ke j

$P=$ Nilai akhir kepraktisan

$n=$ Banyak peserta didik

$m$ =Banyak kriteria

Analisis uji kepraktisan hasil dari angket respon siswa berpedoman pada abel 2 berikut (Hobri, 2010).

\section{Tabel 2. Kriteria Kepraktisan}

\begin{tabular}{cc}
\hline Kriteria & Tingkat Kepraktisan \\
Kepraktisan & \\
$\boldsymbol{P}=\mathbf{5}$ & Sangat Tinggi \\
$\mathbf{4} \leq \boldsymbol{P}<\mathbf{5}$ & Tinggi \\
\hline $\mathbf{3} \leq \boldsymbol{P}<\mathbf{4}$ & Sedang \\
\hline $\mathbf{2} \leq \boldsymbol{P}<\mathbf{3}$ & Rendah \\
\hline $\mathbf{1} \leq \boldsymbol{P}<\mathbf{2}$ & Sangat Rendah \\
\hline
\end{tabular}

Media pembelajaran MAVENDI dikatakan praktis apabila nilai kepraktisan lebih dari 3 dengan tingkat kepraktisan Sedang. Apabila nilai kepraktisan tidak memenuhi kriteria maka peneliti harus melakukan revisi terhadap media tersebut.

\section{Keefektifan Media Pembelajaran}

Uji keefektifan media pembelajaran MAVENDI diperoleh dari observasi keaktifan siswa. Nilai keaktifan siswa secara individu (NKS) dapat dihitung dengan menggunakan persamaan berikut:

$$
\text { NKS }=\frac{\text { jumlah Skor }}{\text { Skor Maks }} \times 100 \%
$$

Setiap siswa dikatakan aktif apabila nilai keaktifan yang diperoleh lebih dari 75 . Observasi keaktifan siswa secara klasikal ditentukan angka rata-ratanya, kemudian dicocokkan dengan kategorinya. Angkaangka tersebut digunakan sebagai tolak ukur yang menunjukkan keaktifan siswa selama proses pembelajaran. Data hasil observasi nilai keaktifan siswa secara klasikal (NKK) dihitung dengan rumus sebagai berikut (Aminoto \& Phatoni, 2014).

$$
\text { NKK }=\frac{\text { Jumlah siswa aktif }}{\begin{array}{c}
\text { Jumlah siswa keseluruhan } \\
\text { Selanjutnya keefektifan media }
\end{array}} \times 100 \%
$$
pembelajaran MAVENDI dapat dilihat berdasarkan kriteria keefektifan pada Tabel 3 berikut (Aminoto \& Phatoni, 2014).

\section{Tabel 3. Kriteria Keefektifan}

\begin{tabular}{cc}
\hline Kriteria Keaktifan & Tingkat Keaktifan \\
\hline $\mathbf{8 1} \%-\mathbf{1 0 0} \%$ & Sangat Aktif \\
\hline $\mathbf{6 1} \%-\mathbf{8 0} \%$ & Aktif \\
\hline $\mathbf{4 1} \%-\mathbf{6 0} \%$ & Cukup Aktif \\
\hline $\mathbf{2 1} \%-\mathbf{4 0} \%$ & Kurang Aktif \\
\hline $\mathbf{0} \%-\mathbf{2 0} \%$ & Tidak Aktif \\
\hline Media pembelajaran MAVENDI
\end{tabular}
dikatakan efektif apabila nilai keaktifan siswa secara klasikal lebih dari $60 \%$ yang memenuhi kriteria aktif.

\section{Hasil dan Pembahasan \\ Validasi Media Pembelajaran}

Media pembelajaran MAVENDI (Magnetic Venn Diagram) dikatakan valid jika validitas gabungan menunjukkan hasil lebih dari $70 \%$. Pada penelitian ini kriteria validitas ditetapkan pada rentang 70\%-85\% sebagai batas minimum.

Hasil validasi draft I media pembelajaran MAVENDI pada materi himpunan memperoleh skor gabungan yaitu $76,74 \%$ seperti pada Tabel 4. Selain itu, terdapat komentar dan saran yang disampaikan oleh validator untuk perbaikan media pembelajaran MAVENDI. 
Tabel 4. Validasi Media Draft I

\begin{tabular}{|c|c|c|c|c|}
\hline \multirow{2}{*}{ No. } & \multirow{2}{*}{ Aspek } & \multicolumn{3}{|c|}{ Validator } \\
\hline & & 1 & 2 & 3 \\
\hline 1. & Aspek Materi & $80 \%$ & $84 \%$ & $80 \%$ \\
\hline 2. & Aspek Isi & $80 \%$ & $73,33 \%$ & $73,33 \%$ \\
\hline \multirow[t]{3}{*}{3.} & Aspek Tampilan & $72 \%$ & $76 \%$ & $76 \%$ \\
\hline & Rata-rata presentase & $77,33 \%$ & $77,78 \%$ & $75,11 \%$ \\
\hline & Validasi Gabungan & & $76,74 \%$ & \\
\hline
\end{tabular}

\begin{tabular}{lllr}
\multicolumn{1}{r}{ Adapun saran dari validator adalah } & lingkaran yang & menyatakan himpunan \\
lambang Semesta terdapat revisi yang & beririsan kurang sesuai karena lingkaran \\
semula lepas pasang, menjadi permanen. & sudah membentuk himpunan yang beririsan \\
Selain itu, pada bagian diagram yang & seperti & Gambar
\end{tabular}
menyatakan himpunan terdapat revisi, yaitu

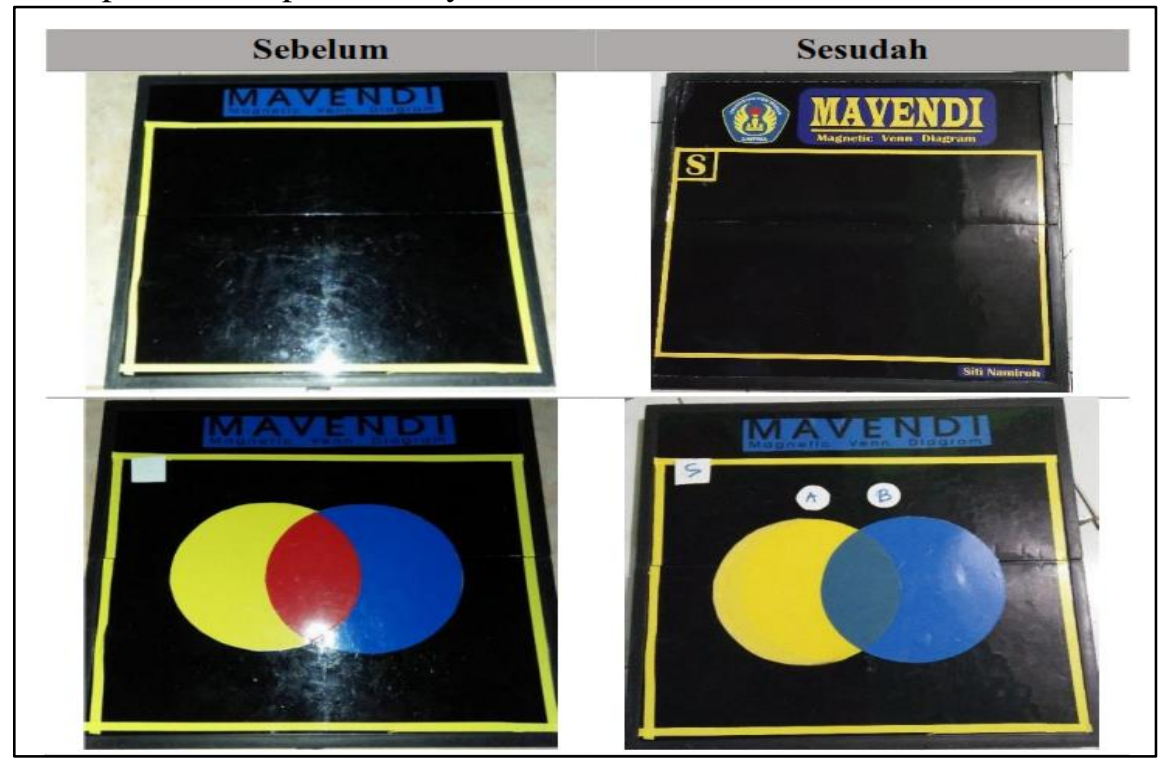

Gambar 1. MAVENDI Sebelum dan Sesudah Direvisi

Revisi dilakukan berdasarkan saran yang diberikan oleh validator. Hasil revisi tersebut kemudian dinyatakan sebagai draft II. Setelah dilakukan revisi (draft II) oleh peneliti maka validasi dilakukan kembali kepada 3 validator sehingga diperoleh hasil validasi dari draft II pada Tabel 5 .

Tabel 5. Validasi Media Draft II

\begin{tabular}{|c|c|c|c|c|}
\hline \multirow{2}{*}{ No. } & \multirow{2}{*}{ Aspek } & \multicolumn{3}{|c|}{ Validator } \\
\hline & & 1 & 2 & 3 \\
\hline 1. & Aspek Materi & $80 \%$ & $80 \%$ & $100 \%$ \\
\hline 2. & Aspek Isi & $80 \%$ & $100 \%$ & $93,33 \%$ \\
\hline \multirow[t]{3}{*}{3.} & Aspek Tampilan & $80 \%$ & $92 \%$ & $92 \%$ \\
\hline & Rata-rata presentase & $80 \%$ & $90,67 \%$ & $95,11 \%$ \\
\hline & Validasi Gabungan & & $88,59 \%$ & \\
\hline
\end{tabular}

\section{Kepraktisan Media Pembelajaran}

Media pembelajaran MAVENDI dikatakan praktis jika pada rentang $3 \leq P<4$ sebagai batas minimum kepraktisan. Pada uji coba terbatas diperoleh hasil angket respon siswa sebesar $\mathrm{P}=4,4$, yang artinya respon siswa terhadap media pembelajaran MAVENDI adalah tinggi. Pada uji coba lapangan diperoleh hasil angket respon siswa sebesar $\mathrm{P}=4,2$ 
yang artinya respon siswa terhadap media pembelajaran MAVENDI adalah tinggi. Dari kedua hasil uji coba tersebut diperoleh kesimpulan bahwa tingkat kepraktisan atau angket respon siswa terhadap media pembelajaran MAVENDI adalah tinggi.

Selaras dengan penelitian yang dikemukakan oleh Handayani, Yuwono, \& Madja (2013) bahwa pengembangan media pembelajaran dikatakan cukup praktis apabila memperoleh skor $2,5 \leq P<$ 3,25. Dengan demikian, media pembelajaran MAVENDI yang dikembangkan cukup praktis yang berarti bahwa MAVENDI dapat digunakan sebagai suatu alternatif media pembelajaran pada materi Himpunan.

\section{Keefektifan Media Pembelajaran}

Media pembelajaran MAVENDI dikatakan efektif apabila nilai observasi keaktifan berada pada rentang 61\%-80\% dengan kriteria aktif. Skor rata-rata yang dihasilkan dari observasi keaktifan 6 siswa dalam uji coba terbatas adalah 66,7 dengan presentase sebesar $100 \%$ yang artinya keaktifan siswa berada di tingkat aktif. Sedangkan skor yang dihasilkan dari observasi keaktifan 12 siswa dalam uji coba lapangan adalah 64,7 dengan presentase sebesar $100 \%$. Yang artinya keaktifan siswa berada di tingkat aktif.

Selaras dengan penelitian yang dikembangkan oleh Sageileppak (2016) bahwa observasi keaktifan dikatakan efektif apabila nilai keaktifan $61 \%-80 \%$ dengan kriteria aktif. Dengan demikian, MAVENDI dapat digunakan sebagai suatu alternatif media pembelajaran pada materi Himpunan, yang dapat meningkatkan keaktifan siswa.

Hasil penelitian juga menunjukkan, pengembangan MAVENDI sebagai media pembelajaran pada materi Himpunan ini disesuaikan dengan perkembangan zaman (era normal baru). Ini sejalan dengan Murtafiah (2010) bahwa pengembangan suatu perangkat pembelajaran sebaiknya disesuaikan dengan keterampilan hidup (life skills) untuk menjadi bekal siswa dalam menghadapi kehidupan. Pengembangan media ini efektif mendukung pembelajaran yang dianjurkan pada era normal baru (Tim
GTK Kemendikbud RI, 2020). Pengembangan MAVENDI ini juga dirancang sesuai dengan karakteristik siswa sehingga siswa aktif dalam kegiatan pembelajaran. Ini sejalan dengan Murtafiah, Sa'dijah, Chandra, \& Susiswo (2019) bahwa perancangan suatu media pembelajaran juga harus disesuaikan dengan karakteristik pebelajar/siswa.

\section{Simpulan dan Saran \\ Simpulan}

Hasil dari pengembangan MAVENDI ini dinyatakan cukup valid dengan presentase sebesar $88,59 \%$. Media ini memperoleh kriteria kepraktisan tinggi dengan nilai akhir pada uji coba terbatas sebesar $\mathrm{P}=4,23$ dan pada uji coba lapangan sebesar $\mathrm{P}=4,23$ berdasarkan angket respon siswa. Media ini dinyatakan efektif dengan memperoleh presentase sebesar $66,7 \%$ pada uji coba terbatas, sedangkan pada uji coba lapangan diperoleh persentasi sebesar $64,7 \%$ dengan kriteria aktif, yang didasarkan pada observasi keaktifan siswa.

\section{Saran}

Bagi guru, MAVENDI dapat digunakan sebagai rujukan untuk meningkatkan keaktifan siswa pada pembelajaran materi Himpunan di era normal baru. MAVENDI dapat dirancang dengan menggunakan bahan kayu berkualitas baik sehingga media yang dirancang dapat digunakan dalam jangka waktu lama untuk siswa-siswa pada angkatan selanjutnya.

Bagi siswa, pentingnya meningkatkan keaktifan belajar siswa di era normal baru. Keaktifan siswa dalam mempelajari materi dapat membantu meningkatkan hasil belajar siswa, karena siswa yang aktif dalam kegiatan belajar mengajar dapat memahami materi dengan baik.

\section{Daftar Pustaka}

Akbar, S. (2013). Instrumen Perangkat Pembelajaran. Bandung: PT Remaja Rosdakarya.

Akbar, Sa'dun. (2013). Instrumen Perangkat Pembelajaran. Bandung: 
Remaja Rosdakarya Offset.

Aminoto, T., \& Phatoni, H. (2014). Penerpan Media E-learning Berbasis Schoology untuk Meningkatkan Aktivitas dan Hasil Belajar Materi Usaha dan Energi. Jurnal Sainmatika, $8(1), 13-29$.

Arfinanti, N. (2014). Lembar Kerja Siswa Pada Materi Pendidikan Matematika Realistik Untuk Siswa SMP / MTs. Jurnal Phenomenon, 4(1), 5-17.

Ariska, M. D., Darmadi, \& Murtafiah, W. (2018). Pengembangan Media Pembelajaran Menggunakan Adobe Flash Berbasis Metakognisi Untuk Meningkatkan Motivasi Belajar Matematika. Edumatica, 08(01 April), 83-97.

Gugus Tugas Percepatan Penanganan COVID-19. (2020). Data Sebaran Covid-19. Retrieved from https://covid19.go.id/

Handayani, I., Yuwono, I., \& Madja, M. S. (2013). Pengembangan Media Pembelajaran Berbantuan Komputer Pada Materi Diagram Venn Untuk Siswa Kelas VII SMP. Jurnal Pendidikan Matematika UM. Retrieved from http://jurnalonline.um.ac.id/

Murtafiah, W. (2010). Pengembangan Lembar Kegiatan Siswa dengan Pembelajaran Matematika Realistik Berbasis Life Skills pada Materi Bangun Ruang Sisi Datar di Kelas VIII SMP. Jurnal Pendidikan MIPA, 2(1), 15-36.

Murtafiah, W., Sa'dijah, C., Chandra, T. D., \& Susiswo, S. (2019). Decision making of the Winner of the National Student Creativity Program in Designing ICT-based Learning Media. TEM Journal, 8(3), 1039-1045. https://doi.org/10.18421/TEM83-49
Murtafiah, W., Sa'dijah, C., Chandra, T. D., Susiswo, \& Zayyadi, M. (2020). Novice and Experienced Mathematics Teachers Decision Making Process in Designing Math Problem. IOP Conf. Series: Journal of Physics: Conf. Series, 1464(012030), 1-6. https://doi.org/10.1088/17426596/1464/1/012030

Sageileppak, M. (2016). Upaya Meningkatkan Keaktifan Belajar Siswa Menggunakan Media "Papan Tempel Gambar" Mata Pelajaran IPS. Jurnal Pendidikan Guru Sekolah Dasar, 20(5), 24-35.

Sugiyono. (2017). Metode Penelitian \& Pengembangan. Bandung: Alfabeta.

Sundayana, R. (2013). Media Pembelajaran Matematika. Bandung: Alfabeta.

Thiagarajan, S., Semmel, D. S., \& Semmel, M. I. (1974). Instructional Development for Training Teachers of Exceptional Children: A Sourcebook. Indiana: Indiana University.

Tim GTK Kemendikbud RI. Panduan Pembelajaran di Era Kenormalan Baru (2020).

Vitasari, R., Joharman, \& Suryandari, K. C. (2013). Peningkatan Keaktifan dan Hasil Belajar Matemaika Melalui Problem Based Learning Siswa Kelas V SD Kutosari Kebumen. Kalam Cendekia PGSD, 4(3), 1-8.

WHO. (2020). Coronavirus disease (COVID-19) pandemic. Retrieved from https://www.who.int/

Zayyadi, M., Hasanah, S. I., \& Muhaimin, A. (2018). Pengembangan Lembar Kegiatan Siswa dalam Pemecahan Masalah Matematika Dengan Pendekatan Metakognitif. BRILIANT: Jurnal Riset Dan Konseptual, 3(4), 401-410. 